\title{
Recurrent hardgrounds and their significance for intra-basinal correlations: a case study of upper Bathonian rocks from the western margin of the Indian craton
}

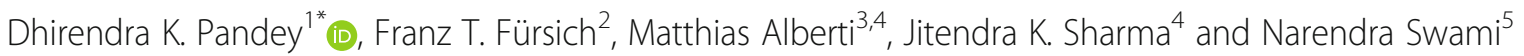

\begin{abstract}
A set of two to three prominent hardgrounds can be traced for more than $40 \mathrm{~km}$ from east to west within the Jurassic succession of the Jaisalmer Basin at the western margin of the Indian Craton. The hardgrounds started to form under subtidal conditions in a mixed carbonate-siliciclastic setting during the last phase of a transgressive systems tract, i.e. the maximum flooding zone. The age difference between the hardgrounds is very small, but they differ lithologically. Typically, the stratigraphically oldest hardground occurs at the top of a 1-m-thick calcareous sandstone. It is characterized by a spectacular megaripple surface encrusted with oysters and subsequently occasionally bored by bivalves. The hardground is overlain by $10-25 \mathrm{~cm}$ of biowackestone to biopackstone, at the top of which another hardground is developed. This second hardground is characterized by abundant bivalve (Gastrochaenolites isp.) and "worm" borings (Trypanites and Meandropolydora isp.) and occasional oyster encrustations. The third hardground can be found within the overlying 60-cm-thick, bioturbated, fossiliferous silty marly packstone. It shows common to abundant oyster encrustations and occasional borings together with reworked concretions. The individual hardground can be well recognized throughout the basin based on lithology and biotic components. The second hardground (biowackestone to biopackstone) with abundant bivalve and worm borings is most prominent and widespread. Lithostratigraphically, these three hardground surfaces belong to the uppermost part of the Bada Bag Member of the Jaisalmer Formation. Based on ammonites, such as Perisphinctes congener (Waagen), brachiopods, and corals, this interval of the Bada Bag Member has been assigned a late Bathonian age. The entire succession above the first hardground is bioturbated up to the overlying marly silt of the Kuldhar Member of the Jaisalmer Formation, which is already Callovian in age. The characteristic hardground lithologies, together with the ammonite record, allow long-distance correlations within the basin emphasizing their importance as valuable marker horizons. The biotic components associated with the hardgrounds and alternating sediments represent high diversity community relicts developed in shallow-water, open-marine environments.
\end{abstract}

Keywords: Hardgrounds, Stratigraphy, Palaeoenvironment, Jurassic, Jaisalmer Basin

\footnotetext{
* Correspondence: dhirendra.pandey@manipal.edu; dhirendrap@hotmail.com

${ }^{1}$ Earth and Planetary Sciences Group, Manipal Center for Natural Sciences,

Centre of Excellence, Dr. TMA Pai Planetarium Building, Manipal Academy of

Higher Education, Manipal 576104, India

Full list of author information is available at the end of the article
} 


\section{Introduction}

Kachchh Basin and Jaisalmer Basin are two neighbouring sedimentary basins at the western margin of the Indian Craton (Fig. 1a; e.g., Biswas 1971, 1977, 1991; Das Gupta 1975; Krishna 1987, 2017; Fürsich et al. 2001, 2013; Pandey et al. 2014), about $400 \mathrm{~km}$ apart. These basins are well known for numerous fossiliferous horizons, shell beds, well-preserved trace fossils, condensed horizons, reworked concretions, hardgrounds, cyclic sedimentation and lateral thickening and thinning of stratigraphic units within the Jurassic succession (e.g., Singh 1989; Fürsich et al. 1991, 1992, 2013, 2017, 2018; Fürsich and Oschmann 1993; Paul et al. 2018). The peak of the first transgression, which inundated the basins simultaneously, has been dated as late Bajocian (Singh et al. 1982; Pandey and Fürsich 1994; Pandey et al. 2006a, 2006b; Pandey and Choudhary 2007). In both basins, Jurassic sediments range from non-marine siliciclastics to marine mixed carbonate-siliciclastics to pure marine carbonate mud. The lithostratigraphic scheme of the basins has been modified from time to time (Waagen 1875; Das Gupta 1975; Biswas 1977; Kachhara and Jodhawat 1981; Fürsich et al. 2001, 2013; Pandey et al. 2014), but a complete, regionally applicable lithostratigraphy of both basins has yet to be formulated.

Fürsich et al. (1992) recorded for the first-time hardgrounds in the Jaisalmer Basin. Further field investigations in other parts of the basin have revealed that these hardgrounds are widespread throughout the basin from east to west and are therefore excellent marker beds of the upper Bathonian rocks. This is very significant for stratigraphic correlation in the Jaisalmer Basin, where stratigraphic units commonly disappear or change in lithological character laterally. These hardgrounds record temporal changes in lithology, from mixed carbonate-siliciclastic to carbonate, and in faunal composition, which consequently reflect on the depositional setting. The present study deals with a detailed description of hardgrounds in the Jaisalmer Basin and discusses the implication of their wide extension.

\section{Geological setting of the Jaisalmer Basin}

The Jaisalmer Basin covers the entire Jaisalmer district of western Rajasthan. Geologically, it is a pericratonic shelf basin on the northwestern slope of the Indian Craton, situated along the southern margin of the Tethys Sea. The strata in the basin range from the Precambrian to the recent with several depositional gaps (Pandey et al. 2006a, 2006b, 2014). Tectonically, it became active after Mesozoic times and has been divided into four structural units: (a) a median northwest-southeast trending raised Mari-Jaisalmer arch, (b) a synclinal Shahgarh sub-basin in the southwest, (c) the Kishangarh sub-basin in the north and northeast, and (d) the
Miyajlar sub-basin in the south (Fig. 1b; Rao 1972). Lithostratigraphically, the Jurassic strata have been grouped into the Lathi, Jaisalmer, Baisakhi and Bhadasar Formations, which are further divided into members (Fig. 1c; Table 1). The Jaisalmer Formation, the most fossiliferous formation of the basin, has been divided into the Hamira, Joyan, Fort, Bada Bag, Kuldhar and Jajiya Members. The outcrops of these members can be encountered around the city of Jaisalmer. The older parts of the Jaisalmer Formation (Hamira and Joyan Members) yield only few fossils, which are exclusively benthic. The overlying Fort Member has yielded several benthic faunal elements together with belemnites and a few middle Bathonian ammonites (Prasad et al. 2007; Pandey et al. 2014). The benthic macrofauna is characterized by abundant infaunal and epifaunal bivalves, high-spired gastropods, regular echinoids, corals, and brachiopods in decreasing order of abundance (Pandey et al. 2006b, 2009a, 2014). The older part of the next younger Bada Bag Member is also very poor in macrofaunal diversity. The most common fossils are small-sized rhynchonellid brachiopods (Mukherjee 2009, 2010, 2017; Pandey et al. 2014). In contrast to these lower faunal horizons, the uppermost part of the Bada Bag Member and the Kuldhar Member contain prolific benthic as well as nektic macroinvertebrates (Pandey et al. 2012, 2014), which suggests a distinct change in the environmental parameters. Coincidently, this was also the time-interval, during which the hardgrounds formed. These hardgrounds are confined to the uppermost part of the Bada Bag Member, which based on the records of an index ammonite, Perisphinctes congener (Waagen), and other associated ammonites (Macrocephalites formosus), brachiopods and corals have been assigned a late Bathonian age (Callomon 1993; Jain 2008; Pandey et al. 2014). The overlying Kuldhar Member is characterized by a highly fossiliferous gypsiferous marly silt with several thin, moderately- to well-cemented interbeds of golden ooid-bearing packstones, and occasional shell beds. The fossils recorded from this member are terebratulids (Bihenithyris, Aulacothyris), rhynchonellids (Septirhynchia), bivalves, gastropods, nautiloids, ammonites (Macrocephalites semilaevis, M. chariensis, Reineckeia anceps, Subkossmatia opis, and Collotia gigantea), belemnites, echinoids, crinoids, corals, foraminifers, ostracods and trace fossils. The ammonites and brachiopods clearly suggest a Callovian age of this unit (Kalia and Chowdhury 1983; Krishna 1987; Jain 2008; Pandey et al. 2009b, 2010, 2014).

The youngest Jajiya Member consists of thick, low-angle cross-bedded fossiliferous ooidal packstone to ooidal rudstone, and fine- to medium-grained calcareous sandstone. Rhynchonellids, terebratulids, bivalves, gastropods, ammonites, belemnites, crinoids and corals are common. Based on ammonites, the 

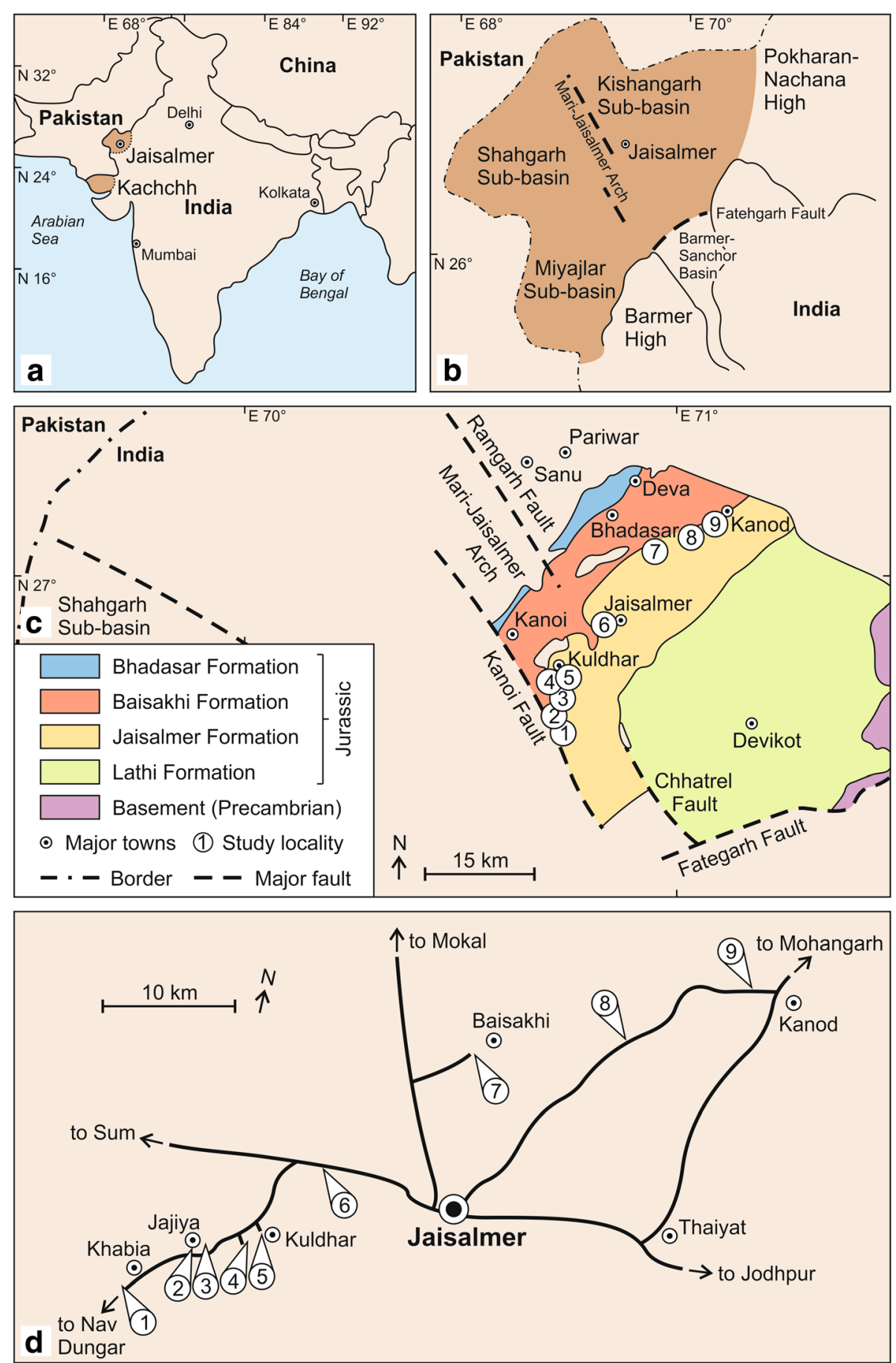

Fig. 1 a Outline map of India showing the location of the Jaisalmer and Kachchh Basins; b Tectonic sketch map of the Jaisalmer Basin (modified after Biswas 1982; Misra et al. 1993); c Geological sketch map of the Jaisalmer Basin showing the outcrops of the Jaisalmer Formation and localities of the three investigated hardgrounds (modified after Das Gupta 1975; Pandey et al. 2014); d Road map showing the investigated localities: 1-Nav Dungar section, 2-River section W of Jajiya village, 3-River section E of Jajiya village, 4-Kuldhar Nala section, 5-Kuldhar River section, 6-11 km milestone section, along the Jaisalmer-Sum road, 7-Gharoi River section, W of Baisakhi village, 8-River section 6 km W of Hadda and $9 \mathrm{~km}$ E of Jethwai villages, and 9-Kanod River section

member has been dated as Oxfordian (Kachhara and Jodhawat 1981; Krishna 1987; Prasad 2006; Sharma and Pandey 2016).

\section{Hardgrounds}

Hardgrounds are surfaces of synsedimentarily-cemented layers that have been exposed on the seafloor. Carbonate 
Table 1 Lithostratigraphic scheme of the Jurassic strata of the Jaisalmer Basin (modified after Pandey and Pooniya 2015; Alberti et al. 2017)

\begin{tabular}{|c|c|c|}
\hline Stage & Formation & Member \\
\hline \multirow{2}{*}{$\begin{array}{l}\text { ?Lower Cretaceous } \\
\text { Tithonian }\end{array}$} & \multirow{2}{*}{ Bhadasar } & Mokal \\
\hline & & Kolar Dungar \\
\hline \multirow[b]{2}{*}{$\begin{array}{l}\text { Tithonian } \\
\text {-Oxfordian }\end{array}$} & \multirow[b]{2}{*}{ Baisakhi } & Lanela $\Gamma_{\varepsilon}$ \\
\hline & & $\begin{array}{ll}\text { Rupsi } \\
\text { Basal }\end{array}$ \\
\hline Oxfordian & \multirow{6}{*}{ Jaisalmer } & Jajiya \\
\hline Callovian & & Kuldhar \\
\hline Mid.-Upper Bathonian & & Bada Bag \\
\hline \multirow{3}{*}{$\begin{array}{l}\text { Lower Bathonian } \\
\text {-Bajocian }\end{array}$} & & Fort \\
\hline & & Joyan \\
\hline & & Hamira \\
\hline \multirow{2}{*}{$\begin{array}{l}\text { Bajocian } \\
\text {-Lower Jurassic }\end{array}$} & \multirow{2}{*}{ Lathi } & Thaiat \\
\hline & & Odania \\
\hline
\end{tabular}

hardgrounds are more common than siliciclastic ones (Taylor and Wilson 2003). The synsedimentary cementation takes place some centimetres below the sedimentwater interface. Hardgrounds provide extensive substrate for cementing and boring organisms. The composition of the associated organisms depends on environmental parameters such as sediment type, rate of sedimentation, and water energy. Hardgrounds preferentially formed during so-called calcite sea intervals in the geological record, characterized by dissolution of aragonite and high precipitation of low-magnesium calcite (Palmer and Wilson 2004). In some cases, hardgrounds show a cyclic pattern (Puga-Bernabéu and Betzler 2008). In the course of the Phanerozoic, the composition of hardground communities changed, e.g., thick calcitic bryozoan and echinoderm encrustations prevailed in the Ordovician and Silurian, whereas oyster and serpulid encrustations and bivalve (Gastrochaenolites), "worm" (Trypanites and Meandropolydora) and sponge (Entobia) borings dominated in the Jurassic and Cretaceous (Fürsich 1979; Fürsich et al. 1992; Taylor and Wilson 2003; Palmer and Wilson 2004).

\section{Materials and methods}

The study is the result of geological field work in the Jaisalmer Basin of western India in the years 2014, 2016, and 2017. During these surveys several localities exposing the described hardgrounds were discovered, and detailed sections were measured. Ammonites were collected in order to assign ages to the different stratigraphic horizons (e.g., Pandey et al. 2014, 2018; Sharma and Pandey 2016). Furthermore, representative rock samples were cut and the surfaces were polished to study the composition of the individual hardgrounds and discover differences between hardgrounds of different localities.

\section{Results}

A set of two to three recurrent hardgrounds has been traced within the upper Bathonian Bada Bag Member of the Jaisalmer Formation from the southwestern to eastern part of the Jaisalmer Basin (Figs. 2, 3 ). The hardground surfaces have been investigated at the following localities:

(1) Nav Dungar section in the southwestern part of the basin $\left(26^{\circ} 47^{\prime} 51.06^{\prime \prime} \mathrm{N}, 70^{\circ} 41^{\prime} 25.44^{\prime \prime} \mathrm{E}\right)$;

(2) River section W of Jajiya village $\left(26^{\circ} 50^{\prime} 9.26^{\prime \prime} \mathrm{N}, 70^{\circ}\right.$ $\left.44^{\prime} 2.87^{\prime \prime} \mathrm{E}\right)$;

(3) River section E of Jajiya village $\left(26^{\circ} 50^{\prime} 41.35^{\prime \prime} \mathrm{N}, 70^{\circ}\right.$ 44'36.14"'E);

(4) Kuldhar Nala section (26 $\left.51^{\prime} 02.8^{\prime \prime} \mathrm{N}, 70^{\circ} 46^{\prime} 17.0^{\prime \prime} \mathrm{E}\right)$;

(5) Kuldhar River section (26 $\left.51^{\prime} 35.4^{\prime \prime} \mathrm{N}, 70^{\circ} 47^{\prime} 04.7^{\prime \prime} \mathrm{E}\right)$;

(6) $11 \mathrm{~km}$ milestone section, west of Jaisalmer city along the Jaisalmer-Sum road $\left(26^{\circ} 55^{\prime} 3.60^{\prime \prime} \mathrm{N}, 70^{\circ}\right.$ $\left.48^{\prime} 37.26^{\prime \prime} \mathrm{E}\right)$;

(7) Gharoi River section, W of Baisakhi village $\left(27^{\circ} 01^{\prime}\right.$ $\left.14.51^{\prime \prime} \mathrm{N}, 70^{\circ} 53^{\prime} 37.544^{\prime \prime} \mathrm{E}\right)$;

(8) River section $6 \mathrm{~km} \mathrm{~W}$ of Hadda and $9 \mathrm{~km} \mathrm{E} \mathrm{of}$ Jethwai villages $\left(27^{\circ} 03^{\prime} 33.06^{\prime \prime} \mathrm{N}, 71^{\circ} 00^{\prime} 25.08^{\prime \prime} \mathrm{E}\right)$;

(9) Kanod River section in the eastern part of the basin $\left(27^{\circ} 07^{\prime} 7.08^{\prime \prime} \mathrm{N}, 71^{\circ} 05^{\prime} 18.30^{\prime \prime} \mathrm{E}\right)$.

These localities, about $1.5 \mathrm{~km}$ to $18 \mathrm{~km}$ away from each other, extend laterally for more than $40 \mathrm{~km}$ from southwest to northeast within the basin (Fig. 1d). The thickness of the rock unit containing the three hardgrounds, ranges from $0.5 \mathrm{~m}$ to $3 \mathrm{~m}$ between localities 1 to 9. Stratigraphically the hardgrounds occur within upper Bathonian strata, as evident by records of the ammonites Macrocephalites madagascariensis, M. triangularis, and Perisphinctes congener, the brachiopods Plectoidothyris jaisalmerensis and Cryptorhynchia sp., and the corals Craterastraea crateriformis, Collignonastraea meandra, Periseris cf. elegantula (Krishna 1987; Jain 2008; Pandey et al. 2009a, 2014; Mukherjee 2010). They vary in lithology from calcareous sandstone/rudstone/packstone to wackestone/mudstone. The individual hardgrounds can easily be recognized throughout the basin because of their characteristic lithology and dominant faunal components. Typically, the stratigraphically oldest hardground (HG I) is found on top of an at most 1.5-m-thick sedimentary unit, characterized by brownish or pinkish yellow, trough 

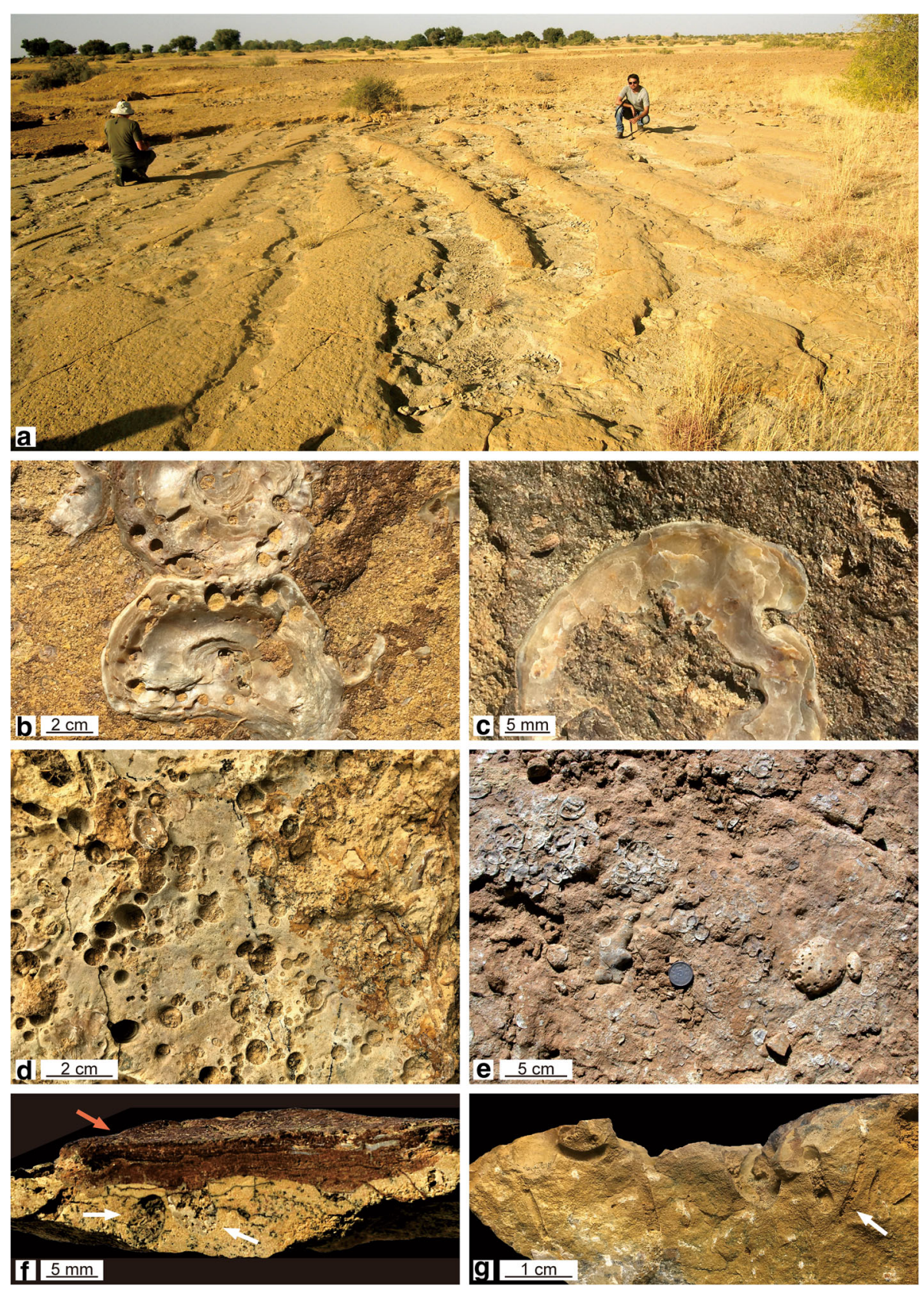

Fig. 2 Field photographs. a Truncated megaripple surface of HG I exposed, River section E of Jajiya village (locality 3); $\mathbf{b}$ and c Close-up views of encrusting oysters on HG I, which are occasionally bored, Kuldhar River section (locality 5). Note shells and borings are covered with a thin iron crust; $\mathbf{d}$ Close-up view of HG II showing Gastrochaenolites, $11 \mathrm{~km}$ milestone section, along the Jaisalmer-Sum road (locality 6). Note irregular outline of the bored hardground surface; e Close-up view of HG III showing oysters encrustation and bored pebbles, $11 \mathrm{~km}$ milestone section, along the Jaisalmer-Sum road (locality 6); f Polished cross-section of HG II showing bivalve borings (Gastrochaenolites isp.; white arrows) and the stromatolitic ferruginous crust (red arrow), Kuldhar River section (locality 5); g Broken cross-section of HG II showing worm borings (Trypanites isp.; arrow), Kanod River section (locality 9)

cross-bedded, partially bioturbated, ooid- and bioclast-bearing calcareous sandstone to rud-/pack -/grainstone with a megaripple surface (Figs. 2a, 4). Trace fossils include Thalassinoides suevicus (common), Ophiomorpha (occasional) and Siphonichnus (rare). The hardground surface is encrusted with oysters (Liostrea and Nanogyra) and occasionally bored to a depth of $<1 \mathrm{~cm}$ (abundant Gastrochaenolites, rare Meandropolydora; Figs. 2b, c, 5). At locality 4 , the oysters form small patch reefs, several decimeter in lateral extent and less than $10 \mathrm{~cm}$ in height. The megaripple surface, Thalassinoides, encrusted shells 


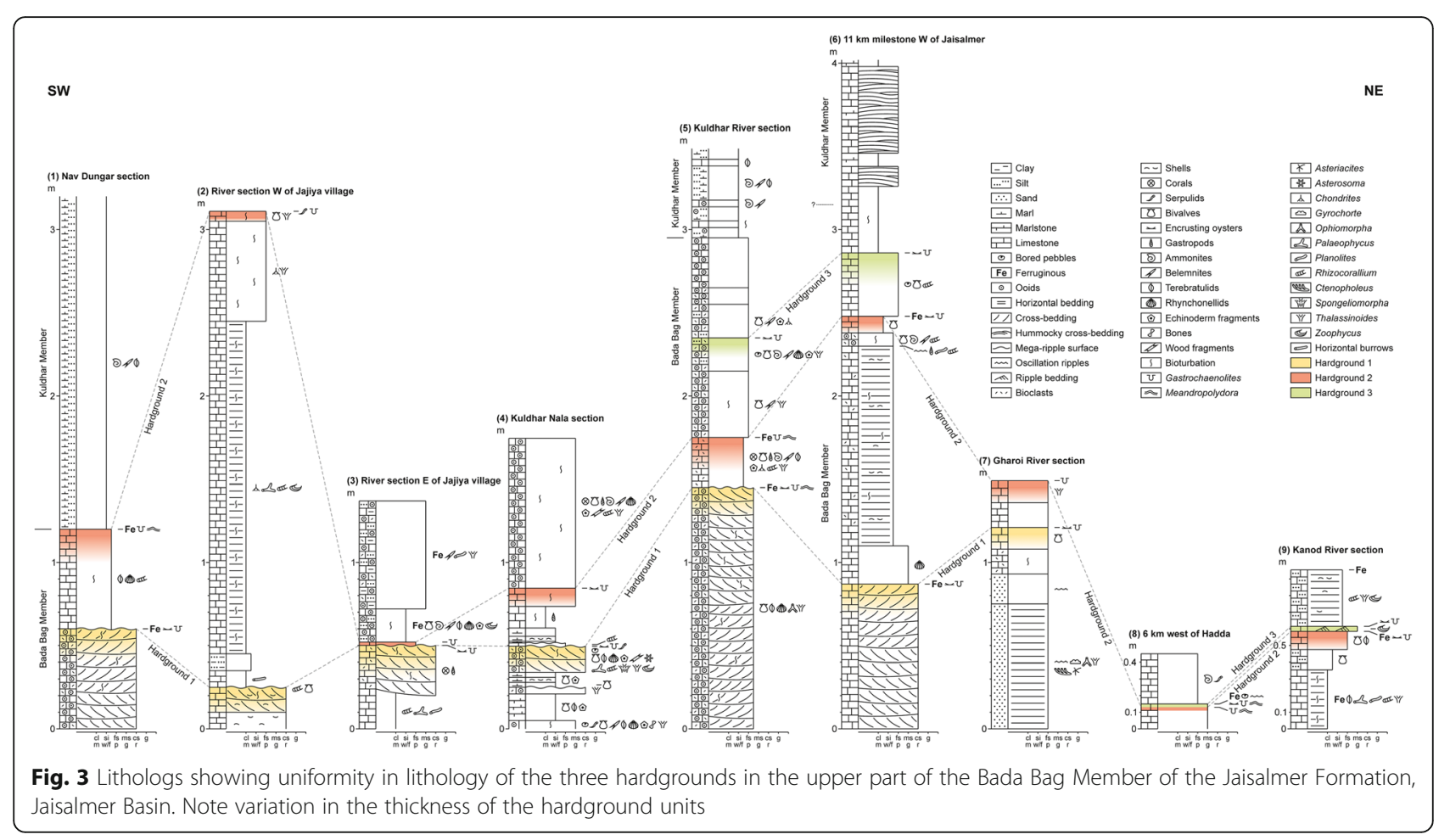

and borings at locality 5 are covered with a thin iron crust that is developed also at most other localities. Other body fossils from this bed are limids, pectinids, rhynchonellids and terebratulids. The best outcrops of this hardground surface are in the localities 1, 3 and 5 . In other areas, such as at the $11 \mathrm{~km}$ milestone section, west of Jaisalmer (locality 6), it either has been anthropogenically removed for building blocks or is covered by the overlying biowackestone to biopackstone unit (locality 4).

The second hardground (HG II) generally forms the top of a 30- to more than 200-cm-thick white mudstone to bio-wackestone. This hardground is characterized by bivalve and "worm" borings (abundant Gastrochaenolites and occasional Meandropolydora and Trypanites). The different diameters of the bivalve borings indicate several phases of colonization and erosion. The borings extend to a depth of up to $10 \mathrm{~mm}$ (Fig. 2f). In case of Trypanites, maximum depth recorded is $20 \mathrm{~mm}$ (Fig. 2g). At three localities, oysters sporadically encrust the surface (Fig. 2d). This hardground has an irregular relief which is covered with a ferruginous stromatolitic crust (Fig. 2f). The fossils recorded from this unit are brachiopods (terebratulids), gastropods (Pleurotomaria), bivalves (Nanogyra, Chlamys, and pholadomyid bivalves, such as Homomya and Pholadomya in life position), cephalopods (belemnites and ammonites), corals, echinoid spines, crinoid ossicles, ophiuroid ossicles, and trace fossils (Chondrites, Rhizocorallium commune, and Thalassinoides). The second carbonate hardground with

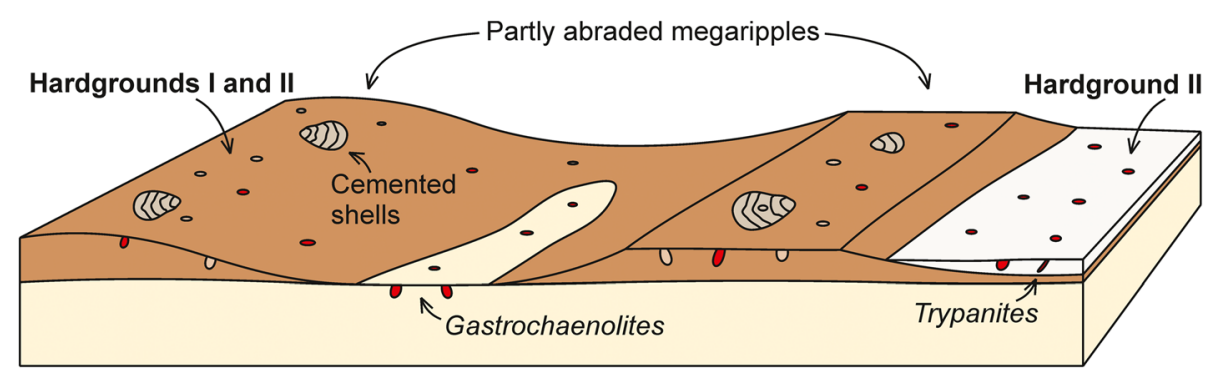

Fig. 4 Sketch showing the relationship between the three beds exhibiting borings associated with the hardgrounds I and II at the River section $\mathrm{E}$ of Jajiya village (locality 3). The two hardgrounds are clearly superimposed as is shown by the abraded and subsequently bored top of some of the megaripples. The borings of the two hardgrounds differ in their fill (shown by different colours). Note that during hardground phase II, erosion also affected the bed underlying $\mathrm{HG}$ I 


\section{Hardground III}

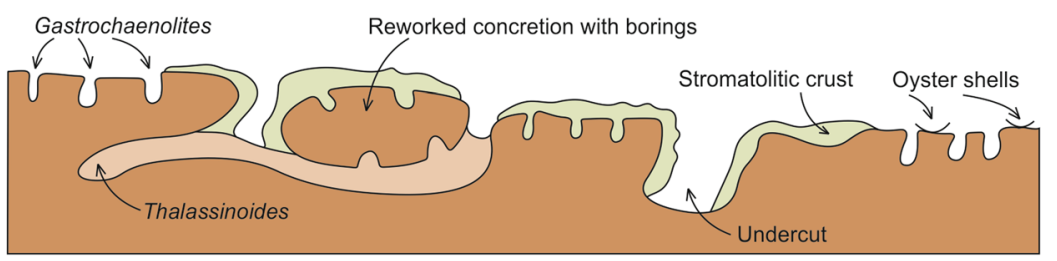

\section{Hardground II}
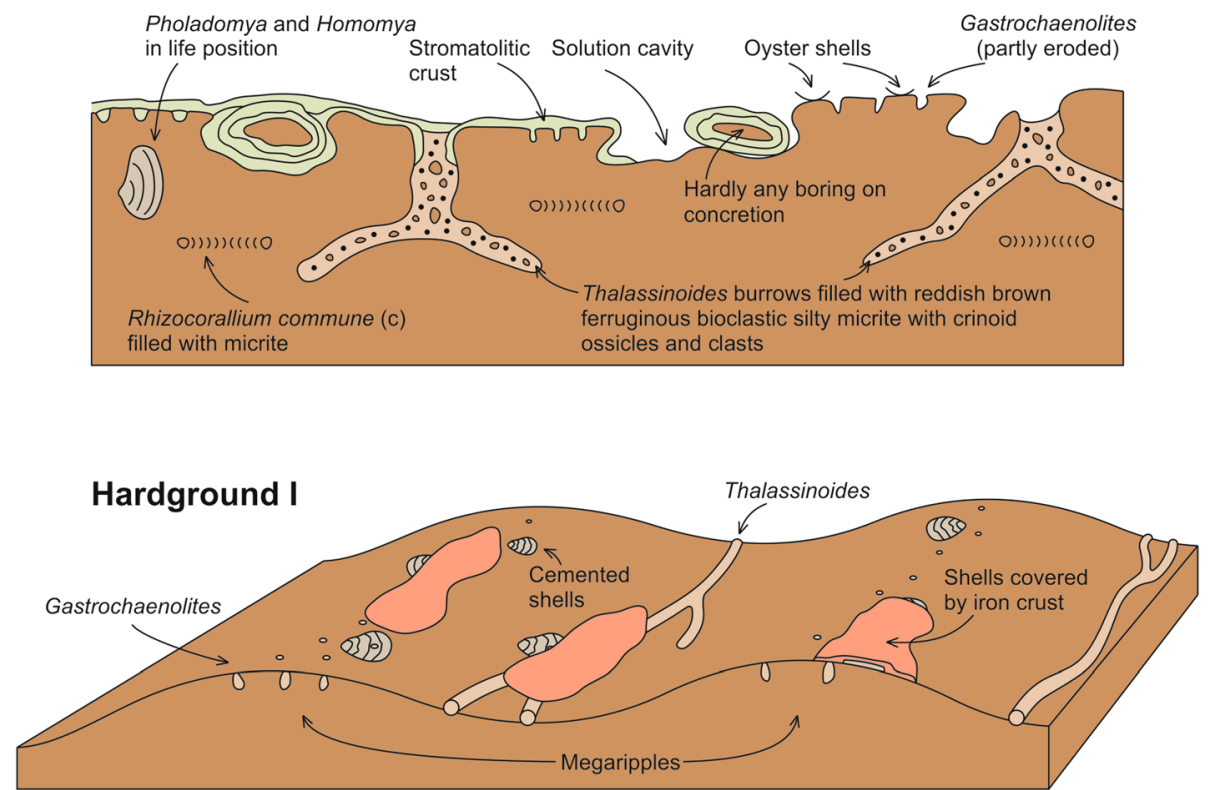

Fig. 5 Sketch diagrams of Hardgrounds I, II and III in the Bada Bag Member of the Kuldhar River section (locality 5) (modified after Fürsich et al. 1992; Pandey et al. 2014). c Common

abundant bivalve and worm borings is widespread and commonly exposed in the river bed at Nav Dungar, southwest of Jaisalmer (locality 1) to near Kanod village, northeast of Jaisalmer (locality 9).

The third hardground (HG III) typically forms the top of a 40- to 60 -cm-thick, bioturbated, fossiliferous, silty, marly, ooid-bearing packstone with bored and encrusted clasts of white mudstone to biowackestone of the underlying unit containing HG II (Fig. 2e). It is characterized by encrusting oysters and a ferruginous stromatolitic crust. Oyster shells also occur scattered within the sediment, occasionally bored with Meandropolydora. The fossils in this unit are bivalves (commonly oysters), brachiopods (rhynchonellids), belemnites, ammonites (Macrocephalites formosus and Perisphinctes congener), echinoid spines, crinoids, etc. The best outcrops of this hardground are in river sections, at Kuldhar village, at the $11 \mathrm{~km}$ milestone section, west of Jaisalmer city and west of Kanod village (localities 5, 6 and 9).

\section{Discussion}

The biogenic components, including trace fossils, associated with these hardgrounds and the intervening sediments, represent relicts of high-diversity communities indicative of shallow-water, open marine environments. The formation of the hardgrounds started under subtidal conditions in a mixed carbonate-siliciclastic setting during the last phase of a transgressive systems tract (Pandey et al. 2010, 2014). The features of the upper Bathonian hardgrounds recorded at the nine localities (Figs. 1, 3) are summarized in Table 2.

Although the lower two hardgrounds and their associated fauna at the Kuldhar River section have been described and interpreted in detail by Fürsich et al. (1992), their lateral extension had not been explored at that time. In the following discussion, after interpreting the main features shown by the hardgrounds, we concentrate on the palaeoenvironmental, stratigraphic, and sequence stratigraphic significance of the three hardgrounds and discuss their palaeogeographic and palaeoclimatic implications. 
Table 2 Features of the hardgrounds in the upper part of the Bada Bag Member of the Jaisalmer Formation, Jaisalmer Basin. HG Hardground, S Softground stage, H Hardground stage, $r$ Rare, o Occurring, c Common, a Abundant, + Present, - Absent

\begin{tabular}{|c|c|c|c|c|c|c|}
\hline Locality & $\begin{array}{l}\text { Hardground } \\
\text { relief }\end{array}$ & $\begin{array}{l}\text { Microfacies/ } \\
\text { Sedimentary } \\
\text { structures }\end{array}$ & Fe-crust & Encrusters & Trace fossils & Associated fauna \\
\hline $\begin{array}{l}\text { (1a) Nav } \\
\text { Dungar HG I }\end{array}$ & $\begin{array}{l}\text { Megaripple } \\
\text { (obscure) }\end{array}$ & Ooidal biorudstone & + & Oysters & H: Gastrochaenolites (c) & \\
\hline $\begin{array}{l}\text { (1b) Nav } \\
\text { Dungar HG ॥ }\end{array}$ & Flat & Packstone & + & & $\begin{array}{l}\text { S: Rhizocorallium commune } \\
\text { H: Meandropolydora (r), } \\
\text { Gastrochaenolites (a) }\end{array}$ & $\begin{array}{l}\text { Terebratulids, } \\
\text { rhynchonellids }\end{array}$ \\
\hline $\begin{array}{l}\text { (2) Jajiya village } \\
\text { W (HG II) }\end{array}$ & Irregular & Packstone & - & & $\begin{array}{l}\text { S: Thalassinoides suevicus } \\
\text { H: Gastrochaenolites (a) }\end{array}$ & \\
\hline $\begin{array}{l}\text { (3a) Jajiya } \\
\text { village E (HG I) } \\
\text { (Figs. 2a and 4) }\end{array}$ & $\begin{array}{l}\text { Truncated } \\
\text { megaripples }\end{array}$ & Rudstone & - & $\begin{array}{l}\text { Oysters } \\
\text { (0) }\end{array}$ & H: Gastrochaenolites (c) & \\
\hline $\begin{array}{l}\text { (3b) Jajiya } \\
\text { Village E (HG II) } \\
\text { (Fig. 4) }\end{array}$ & $\begin{array}{l}\text { Flat, } \\
\text { preserved } \\
\text { only in } \\
\text { megaripple } \\
\text { troughs }\end{array}$ & $\begin{array}{l}\text { Fine-grained } \\
\text { packstone }\end{array}$ & - & & H: Gastrochaenolites (c) & \\
\hline $\begin{array}{l}\text { (4a) Kuldhar } \\
\text { Nala (HG I) }\end{array}$ & Megaripple & Rudstone & - & $\begin{array}{l}\text { Oysters } \\
\text { (o), } \\
\text { Nanogyra } \\
\text { patch } \\
\text { reefs }\end{array}$ & & Rhynchonellids \\
\hline $\begin{array}{l}\text { (4b) Kuldhar } \\
\text { Nala (HG II) }\end{array}$ & Flat & $\begin{array}{l}\text { Fine-grained } \\
\text { packstone }\end{array}$ & - & & H: Gastrochaenolites (a) & \\
\hline $\begin{array}{l}\text { (5a) Kuldhar } \\
\text { River (HG I) } \\
\text { (Figs. 2b, c } \\
\text { and 5) }\end{array}$ & Megaripple & $\begin{array}{l}\text { Trough cross- } \\
\text { bedded sandy } \\
\text { ooidal biopackstone } \\
\text { to grainstone }\end{array}$ & + & Liostrea & $\begin{array}{l}\text { S: Thalassinoides (c), Siphonichnus, } \\
\text { Ophiomorpha (o) } \\
\text { H: Gastrochaenolites } \\
\text { (o), Meandropolydora (r) }\end{array}$ & $\begin{array}{l}\text { Limids, pectinids, } \\
\text { rhynchonellids, } \\
\text { terebratulids }\end{array}$ \\
\hline $\begin{array}{l}\text { (5b) Kuldhar } \\
\text { River (HG II) } \\
\text { (Fig. 5) }\end{array}$ & Irregular & $\begin{array}{l}\text { Silty biowackestone } \\
\text { to biopackstone }\end{array}$ & $\begin{array}{l}+ \\
\text { stromatolitic }\end{array}$ & & $\begin{array}{l}\text { S: Chondrites, Rhizocorallium commune, } \\
\text { Thalassinoides H: Gastrochaenolites } \\
\text { (a), Meandropolydora (o) }\end{array}$ & $\begin{array}{l}\text { Terebratulids, Nanogyra, } \\
\text { Chlamys, Homomya, } \\
\text { Pholadomya, Pleurotomaria, } \\
\text { corals echinoid spines, } \\
\text { crinoid ossicles, }\end{array}$ \\
\hline $\begin{array}{l}\text { (5c) Kuldhar } \\
\text { River (HG III) } \\
\text { (Fig. 5) }\end{array}$ & Irregular & $\begin{array}{l}\text { Silty, marly, ooid- } \\
\text { bearing packstone }\end{array}$ & $\begin{array}{l}+ \\
\text { stromatolitic }\end{array}$ & Oysters & H: Meandropolydora (o) & $\begin{array}{l}\text { Oysters (c), rhynchonellids } \\
\text { echinoid spines, crinoid } \\
\text { ossicles }\end{array}$ \\
\hline $\begin{array}{l}\text { (6a) } 11 \mathrm{~km} \\
\text { milestone W of } \\
\text { Jaisalmer (HG I) }\end{array}$ & $\begin{array}{l}\text { Uneven, } \\
\text { eroded }\end{array}$ & $\begin{array}{l}\text { High-angle cross- } \\
\text { bedded rudstone }\end{array}$ & + & $\begin{array}{l}\text { Nanogyra, } \\
\text { Liostrea }\end{array}$ & H: Gastrochaenolites (a) & \\
\hline $\begin{array}{l}\text { (6b) } 11 \mathrm{~km} \\
\text { Milestone W of } \\
\text { Jaisalmer (HG II) } \\
\text { (Fig. 2d) }\end{array}$ & Irregular & Ooidal biopackstone & + & Oysters & $\begin{array}{l}\text { S: Planolites, Rhizocorallium commune } \\
\text { H: Gastrochaenolites (a) }\end{array}$ & $\begin{array}{l}\text { Rhynchonellids, oysters, } \\
\text { Ctenostreon, high-spired } \\
\text { gastropods }\end{array}$ \\
\hline $\begin{array}{l}\text { (6c) } 11 \mathrm{~km} \\
\text { milestone } \mathrm{W} \text { of } \\
\text { Jaisalmer (HG } \\
\text { III) (Fig. 2e) }\end{array}$ & Irregular & $\begin{array}{l}\text { Packstone with } \\
\text { bored pebbles }\end{array}$ & - & $\begin{array}{l}\text { Nanogyra } \\
\text { (a) }\end{array}$ & $\begin{array}{l}\text { S: Rhizocorallium commune } \mathrm{H} \text { : } \\
\text { Gastrochaenolites }\end{array}$ & $\begin{array}{l}\text { Oysters, rhynchonellids, } \\
\text { echinoid spines, crinoid } \\
\text { ossicles }\end{array}$ \\
\hline $\begin{array}{l}\text { (7a) Gharoi } \\
\text { River (HG I) }\end{array}$ & Flat & Packstone & - & Nanogyra & H: Gastrochaenolites (r) & Actinostreon \\
\hline $\begin{array}{l}\text { (7b) Gharoi } \\
\text { River (HG II) }\end{array}$ & Flat & Packstone & - & & H: Gastrochaenolites (a) & \\
\hline $\begin{array}{l}\text { (8a) } 6 \mathrm{~km} \mathrm{~W} \mathrm{of} \\
\text { Hadda (HG II) }\end{array}$ & Flat & Packstone & + & Oysters (r) & $\begin{array}{l}\text { H: Gastrochaenolites (a), } \\
\text { Meandropolydora (a) }\end{array}$ & \\
\hline $\begin{array}{l}\text { (8b) } 6 \mathrm{~km} \mathrm{~W} \text { of } \\
\text { Hadda (HG III) }\end{array}$ & Flat & $\begin{array}{l}\text { Packstone to } \\
\text { rudstone with } \\
\text { reworked fine- } \\
\text { grained packstone } \\
\text { clasts }\end{array}$ & - & Oysters & $\begin{array}{l}\text { H: Gastrochaenolites, } \\
\text { Meandropolydora (a) }\end{array}$ & \\
\hline
\end{tabular}


Table 2 Features of the hardgrounds in the upper part of the Bada Bag Member of the Jaisalmer Formation, Jaisalmer Basin. HG Hardground, S Softground stage, H Hardground stage, $r$ Rare, o Occurring, c Common, a Abundant, + Present, - Absent (Continued)

\begin{tabular}{|c|c|c|c|c|c|c|}
\hline Locality & $\begin{array}{l}\text { Hardground } \\
\text { relief }\end{array}$ & $\begin{array}{l}\text { Microfacies/ } \\
\text { Sedimentary } \\
\text { structures }\end{array}$ & Fe-crust & Encrusters & Trace fossils & Associated fauna \\
\hline $\begin{array}{l}\text { (9a) Kanod } \\
\text { River (HG II) }\end{array}$ & Flat & Biopackstone & $\begin{array}{l}+ \\
\text { stromatolitic }\end{array}$ & Oysters & $\begin{array}{l}\text { H: Gastrochaenolites, } \\
\text { Trypanites, Meandropolydora }\end{array}$ & $\begin{array}{l}\text { Brachiopods }(r), \\
\text { bivalves (r) }\end{array}$ \\
\hline $\begin{array}{l}\text { (9b) Kanod } \\
\text { River (HG III) }\end{array}$ & Flat & $\begin{array}{l}\text { Packstone to rudstone } \\
\text { with bored and } \\
\text { encrusted concretions }\end{array}$ & & Oysters & H: Gastrochaenolites & \\
\hline
\end{tabular}

The hardgrounds differ in their lithology (Figs. 4, 5). In particular, HG I is invariably associated with a megaripple surface (which may, however, disappear laterally as at localities 6 and 7) and cross-bedded sandy packstones, grainstones, or rudstones, which at some localities may also be partly bioturbated. Locally, the sand content is so high that the lithology is a bioclastic sandstone. Apart from bioclasts, ooids, coated grains, and intraclasts are common components. In the case of HG II and HG III, the sediment is highly bioturbated, much finer, and corresponds to a peloidal biowackestone to biopackstone (HG II) or silty ooid-bearing biopackstone. This difference in lithology corresponds to different energy regimes preceding hardground formation: The sediments of HG I formed under high-energy conditions with constantly shifting substrates, whereas sediments of HG II and HG III record intermediate energy conditions. These lithological differences probably reflect a position above the fair-weather wave-base in the case of HG I and below this base in case of HG II and HG III. This interpretation is corroborated by the ichnofauna that occurs between the hardgrounds: Abundant Rhizocorallium commune and locally Zoophycos sp. are characteristic of low-energy environments (e.g., Seilacher 1967; Fürsich 1998).

The hardgrounds also differ in their morphology: In addition to the megaripple morphology, HG I usually exhibits a smooth surface due to extensive abrasion. An exception is locality 5 (Kuldhar River section), where early diagenetically lithified burrow fills of Thalassinoides in the megaripple troughs are an additional morphological feature. HG II and HG III, in contrast, exhibit partly smooth and flat, partly irregularly undulating surfaces. In general, these surfaces are not continuous but are interrupted by often steep-sided, patchy depressions, up to $10 \mathrm{~cm}$ deep (Fürsich et al. 1992), which are filled with bioclastic material, often in association with a ferruginous stromatolitic crust. In cross-section, undercuts are visible. Apparently, cementation, which took place some distance below the sediment-water interface, was not uniform, possibly because it started around several laterally-arranged nuclei that with growth gradually, but not invariably, coalesced (concretion model). Alternatively, continuous burrowing activity of decapod crustaceans (producing Thalassinoides) locally prevented the hardening. In any case, after lithification and removal of any overlying soft sediment (see below), the hardground surfaces became abraded and planed off by sediment that was moved across the surface but did not accumulate.

Subsequently to the cementation of the internal sediment layer, erosion removed the overlying soft sediment layer, exposed the lithified layer to the seafloor, and created depressions and undercuts by removing soft sediment between and underneath the cemented layer (e.g., Fürsich 1979; Fürsich et al. 1992). The overlying soft sediment layer may have been only a few centimeters thick but may also have been in the order of several decimeters. The latter must have been the case in HG I at the Kuldhar River section (locality 5), as is shown by the lithified horizontal burrow networks of Thalassinoides in the troughs of the megaripples, which were most likely produced several decimeters below the sediment-water interface.

Evidence of ongoing abrasion are also the truncated flask-shaped bivalve borings (Gastrochaenolites), of which often only the lower part is preserved, and the incorporation of bored and encrusted concretions in HG III. The encrusting and boring fauna of HG I is of low diversity: Apart from Gastrochaenolites, rare Meandropolydora borings are found in some of the hardgrounds. Encrusting faunal elements may be abundant, but their diversity is similarly low. All hardgrounds have been colonized by oysters, large Liostrea and small Nanogyra, which commonly are represented by several generations. Gastrochaenolites borings in Liostrea and abraded cemented oyster shells indicate that the hardground surfaces have been available for colonization for some time interrupted occasionally by shifting sediment. The low diversity may be partly due to present-day erosion of the hardground surfaces, because most of them are exposed in dry river beds where more delicate features of the surface may have become obliterated. Partly, high water energy may have been responsible for the lack of other faunal elements. Encrusting organisms are more diverse where hardgrounds are covered by a ferruginous stromatolitic crust as is the case in HG II and HG III at 
several localities. Fürsich et al. (1992) recognized 13 taxa of encrusting sclerosponges, colonial corals, serpulids, brachiopods, bryozoans, and bivalves between layers of the stromatolitic crust, which also colonized the ceilings of undercuts. This implies that after an initial high-energy period, during which the hardground surfaces were mainly bored and became abraded, the water energy decreased so that a biogenic crust composed of microbial layers and abundant encrusting organisms, in particular serpulids, could become established. As this crust is highly ferruginous, Fürsich et al. (1992) interpreted the microbial layers as having been formed by non-photosynthetic bacteria or cyanobacteria, which precipitated ferric iron layers (Palmer and Wilson 1990). A thin iron crust is present on top of most other hardgrounds as well, but its preservation is generally too poor to allow inferences about its nature. Nevertheless, the iron crust documents a pronounced phase of non-sedimentation.

The sediments between the hardgrounds are highly bioturbated, predominantly micritic, and rich in fossils. The nature of the sediments, burrowing bivalves preserved in growth position, and the trace fossil composition (Thalassinoides, Rhizocorallium commune, Zoophycos, and Chondrites) document a low to moderate water energy. Thus, it appears that the stratigraphic interval, in which the three hardgrounds are found, corresponds to a phase of highly episodic sedimentation with phases of omission and erosion. Based on the ammonites Perisphinctes congener, Macrocephalites madagascariensis, $M$. triangularis Kamptokephalites dimerus and Indosphinctes ex gr. errans/peregrinus in the strata overlying the hardgrounds, the age of the condensed unit is late Bathonian. This condensed interval is an excellent marker unit that can be traced across the basin. Apparently, it formed during a phase of high sea level in the late Bathonian, when input of siliciclastic sediment from the hinterland was greatly reduced. In addition, sediment starvation was probably supported by an arid climate that has been postulated for the neighbouring Kachchh Basin based on faunal, clay mineralogical and stable isotope evidence (Fürsich et al. 2005). Sediment starvation has been so extreme that at some localities two successive hardground surfaces have become superimposed, e.g., in the River section E of Jajiya village (locality 3), where borings of HG II are also found on HG I (Fig. 4). At locality $8,6 \mathrm{~km}$ west of Hadda, HG II and HG III are separated only by a few millimeters. As the relief of HG II is irregular, the two hardground surfaces are locally at the same level. The two events are clearly not contemporaneous. At locality 9, HG II and HG III are also closely associated, spaced by merely $3 \mathrm{~cm}$.

In sequence stratigraphic terms, the hardground interval corresponds to the late transgressive systems tract/ maximum flooding zone of a depositional sequence. The individual hardgrounds are interpreted as the transgressive part of high-frequency transgressive-regressive cycles. The transgressive part of these cycles is represented by a hardground, and the regressive part by the sediment unit between that and the following hardground surface. As is generally the case in such parasequences, the transgressive units are much thinner than the regressive ones (e.g., Van Wagoner et al. 1988; Catuneanu et al. 2011).

In the neighbouring Kachchh Basin, more than 400 $\mathrm{km}$ away, no hardgrounds are developed in the coeval Sponge Limestone member of the Patcham Formation (Fürsich et al. 2013). At the Jumara Dome, this member exhibits instead several horizons of reworked and bored concretions, which - similarly to the hardgrounds in the Jaisalmer Basin - also indicate phases of reduced sedimentation (concretion formation) followed by erosion and colonization by an encrusting and boring biota. An elevated clay content of the micritic sediment may have prevented the formation of extended hardgrounds (Goldring and Kazmierczak 1974). At other localities within the Kachchh Basin (e.g., in the Jhura Dome), coeval strata are represented by flagstones composed of grainstones, which have been interpreted as amalgamated storm-wave deposits and thus did not provide the right conditions for the formation of hardgrounds (Fürsich et al. 2018). Hardground formation is a common phenomenon in many Jurassic shallow epicontinental carbonate regimes (e.g., Purser 1969; Palmer and Fürsich 1974; Fürsich 1979; Gruszczyñski 1979; Wilson and Palmer 1994). They strongly vary in their lateral extent. Their precise correlation with the Jaisalmer hardgrounds is impossible.

The wide, apparently synchronous distribution of the three hardgrounds, which can be followed laterally for several tens of kilometers, suggests that conditions across much of the Jaisalmer shelf basin were fairly uniform. The fine-grained siliciclastic sediments overlying the uppermost hardground indicate a major change in the sedimentation pattern and an end of carbonate sedimentation. Fürsich et al. (2005) postulated a climatic shift in the Kachchh Basin from hot and arid in the late Bathonian to warm and humid in the Callovian. The sedimentation pattern in the Jaisalmer Basin suggests an identical climatic change.

\section{Conclusions}

1) Three recurrent hardground surfaces (HG I, II and III) within the upper part of the Bada Bag Member of the Jaisalmer Formation serve as marker beds for intra-basinal correlation. Previous records of late Bathonian ammonites (such as Perisphinctes 
congener, Macrocephalites madagascariensis, and $M$. triangularis) and brachiopods (Plectoidothyris jaisalmerensis and Cryptorhynchia sp.) from HG III suggest a late Bathonian age of the marker beds. The characteristic lithology and biotic components of individual hardgrounds, extending with only minor lithological changes from the southwestern to northeastern part of the Jaisalmer Basin, allow a very precise correlation within the unit and facilitate stratigraphic correlation of overlying and underlying beds. Although HG I may not be exposed everywhere, the cross-bedding and megaripple surface associated with HG I have been found in almost all the outcrops.

2) The stratigraphic position of these hardgrounds coincides with a sudden change in the environmental parameters involving the transition from a carbonate-dominated to a siliciclasticdominated regime produced by a climatic shift to more humid conditions.

3) The widespread extension of hardgrounds, almost across the entire basin, suggests significant breaks in sedimentation. However, due to the scarcity of ammonites we are unable to comment on the time interval of the hiatus. Altogether, the maximum thickness of upper Bathonian sediments is much lower than in the neighbouring Kachchh Basin (15 $\mathrm{m}$ versus approximately $35 \mathrm{~m}$ ).

4) In sequence stratigraphic terms, the three hardgrounds represent the end of transgressive systems tracts, i.e. maximum flooding zones.

\section{Abbreviations}

cl: Clay; cs: Coarse-grained sand; fs: Fine-grained sand; g: Grainstone; g: Gravel; HG I: Hardground I; HG II: Hardground II; HG III: Hardground III; m: Mudstone; ms: Medium-grained sand; p: Packstone; r: Rudstone; si: Silt; w/f: Wackestone/ floatstone
}

\section{Acknowledgements}

Manipal Academy of Higher Education (MAHE) financially supported the fieldwork in the Jaisalmer Basin and computational work in the Earth Sciences Lab to DKP. FTF also acknowledges Manipal Center for Natural Sciences (MAHE) for giving him the opportunity to work on the manuscript during his visit to Manipal in January 2018. MA gratefully acknowledges financial support by the Alexander von Humboldt Foundation. We thank Sohan Salunkhe, Agharkar Research Institute, Pune, for providing Fig. $2 f$.

\section{Authors' contributions}

DKP, FTF and MA designed research, performed research, acquired the data in the field, analyzed data, and drafted the manuscript. JKS and NS acquired the data in the field and analyzed data. All authors read and approved the final manuscript.

\section{Competing interests}

The authors declare that they have no competing interests.

\section{Publisher's Note}

Springer Nature remains neutral with regard to jurisdictional claims in published maps and institutional affiliations.

\section{Author details}

Earth and Planetary Sciences Group, Manipal Center for Natural Sciences, Centre of Excellence, Dr. TMA Pai Planetarium Building, Manipal Academy of Higher Education, Manipal 576104, India. ${ }^{2}$ FG Paläoumwelt, GeoZentrum Nordbayern, Friedrich-Alexander Universität Erlangen-Nürnberg, Loewenichstraße 28, 91054 Erlangen, Germany. ${ }^{3}$ Institut für Geowissenschaften, Christian-Albrechts-Universität zu Kiel, Ludewig-Meyn-Straße 10, 24118 Kiel, Germany. ${ }^{4}$ Department of Geology, University of Rajasthan, Jaipur 302004, India. ${ }^{5}$ Himalayan Geology Division, Geological Survey of India Northern Region, Lucknow 226024, India.

Received: 13 August 2018 Accepted: 28 November 2018

Published online: 18 December 2018

\section{References}

Alberti, M., D.K. Pandey, J.K. Sharma, N.K. Swami, and A. Uchman. 2017. Slumping in the upper Jurassic Baisakhi formation of the Jaisalmer Basin, western India: Sign of synsedimentary tectonics? Journal of Palaeogeography 6 (4): 321-332.

Biswas, S.K. 1971. Note on the geology of Kutch. The Quarterly Journal of the Geological, Mining, and Metallurgical Society of India 43: 223-235.

Biswas, S.K. 1977. Mesozoic rock-stratigraphy of Kutch, Gujarat. The Quarterly Journal of the Geological, Mining, and Metallurgical Society of India 49 (3-4): $1-51$.

Biswas, S.K. 1982. Rift basins in western margin of India and their hydrocarbon prospects with special reference to Kutch Basin. AAPG Bulletin 66 (10): 14971513.

Biswas, S.K. 1991. Stratigraphy and sedimentary evolution of the Mesozoic basin of Kutch, western India. In Stratigraphy and Sedimentary Evolution of Western India, ed. S.K. Tandon, C.C. Panz, and S.M. Casshyap, 74-103. Nainital: Gyanodaya Prakashan.

Callomon, J.H. 1993. On Perisphinctes congener Waagen, 1875, and the age of the Patcham limestone in the middle Jurassic of Jumara, Kutch, India. Geologische Blätter von NO Bayern 43: 227-246.

Catuneanu, O., W.E. Galloway, C.G.St.C. Kendall, A.D. Miall, H.W. Posamentier, A. Strasser, and M.E. Tucker. 2011. Sequence stratigraphy: Methodology and nomenclature. Newsletters on Stratigraphy 44 (3): 173-245.

Das Gupta, S.K. 1975. A revision of the Mesozoic-tertiary stratigraphy of the Jaisalmer Basin, Rajasthan. Indian Journal of Earth Sciences 2: 77-94.

Fürsich, F.T. 1979. Genesis, environment and ecology of Jurassic hardgrounds. Neues Jahrbuch für Geologie und Paläontologie, Abhandlungen 158: 1-63.

Fürsich, F.T. 1998. Environmental distribution of trace fossils in the Jurassic of Kachchh (western India). Facies 39: 243-272.

Fürsich, F.T., M. Alberti, and D.K. Pandey. 2013. Stratigraphy and palaeoenvironments of the Jurassic rocks of Kachchh — Field guide. Beringeria, Special Issue 7: 1-174.

Fürsich, F.T., M. Alberti, and D.K. Pandey. 2017. Behavioural variants of the trace fossil Gyrochorte. Zitteliana 89: 13-21.

Fürsich, F.T., and W. Oschmann. 1993. Shell beds as tools in basin analysis: The Jurassic of Kachchh. western India. Journal of the Geological Society, London 150 (1): 169-185.

Fürsich, F.T., W. Oschmann, A.K. Jaitly, and I.B. Singh. 1991. Faunal response to transgressive-regressive cycles: Example from the Jurassic of western India. Palaeogeography, Palaeoclimatology, Palaeoecology 85 (3-4): 149-159.

Fürsich, F.T., W. Oschmann, I.B. Singh, and A.K. Jaitly. 1992. Hardgrounds, reworked concretion levels and condensed horizons in the Jurassic of western India: Their significance for basin analysis. Journal of the Geological Society, London 149 (3): 313-331.

Fürsich, F.T., D.K. Pandey, J.H. Callomon, A.K. Jaitly, and I.B. Singh. 2001. Marker beds in the Jurassic of the Kachchh Basin, western India: Their depositional environment and sequence-stratigraphic significance. Journal of the Palaeontological Society of India 46: 173-198.

Fürsich, F.T., I.B. Singh, M. Joachimski, S. Krumm, M. Schlirf, and S. Schlirf. 2005. Palaeoclimate reconstructions of the middle Jurassic of Kachchh (western India): An integrated approach based on palaeoecological, oxygen isotopic, and clay mineralogical data. Palaeogeography, Palaeoclimatology, Palaeoecology 217 (3-4): 289-309.

Fürsich, F.T., A. Uchman, M. Alberti, and D.K. Pandey. 2018. Trace fossils of an amalgamated storm-bed succession from the Jurassic of the Kachchh Basin, India: The significance of time-averaging in ichnology. Journal of Palaeogeography 7 (1): 14-31. 
Goldring, R., and J. Kazmierczak. 1974. Ecological succession in intraformational hardground formation. Palaeontology 17: 949-962.

Gruszczyñski, M. 1979. Ecological succession in upper Jurassic hardgrounds from Central Poland. Acta Palaeontologica Polonica 24 (4): 429-450.

Jain, S. 2008. Integrated Jurassic biostratigraphy: A closer look at nannofossil and ammonite evidences from the Indian subcontinent. Current Science 95 (3): 326-331.

Kachhara, R.P., and R.L. Jodhawat. 1981. On the age of Jaisalmer formation, Rajasthan, India, 235-247. In: Proceedings of IX Indian Colloquium on Micropalaeontology and Stratigraphy. Udaipur.

Kalia, P., and S. Chowdhury. 1983. Foraminiferal biostratigraphy, biogeography, and environment of the Callovian sequence, Rajasthan, northwestern India. Micropaleontology 29 (3): 223-254.

Krishna, J. 1987. An overview of the Mesozoic stratigraphy of Kachchh and Jaisalmer basins. Journal of the Palaeontological Society of India 32: 136-149.

Krishna, J. 2017. The Indian Mesozoic chronicle: Sequence stratigraphic approach, 181. Springer Singapore: Series springer geology.

Misra, P.C., N.P. Singh, D.C. Sharma, A.K. Kakaroo, H. Upadhyay, and M.L. Saini. 1993. Lithostratigraphy of Indian petroliferous basins, document II West Rajasthan Basins, 1-123. KDMIPE: ONGC Publication.

Mukherjee, D. 2009. Taxonomy, Succession and Biogeography of Middle-Upper Jurassic Brachiopods of Jaisalmer. Unpublished G.S.I report of F.S. 2005-2007. In Geological survey of India.

Mukherjee, D. 2010. New record of Plectoidothyris from the middle Jurassic sequence of Jaisalmer Basin, western India: Implications on the easterly brachiopod migrations. Journal of the Geological Society of India 76 (3): 267-274.

Mukherjee, D. 2017. Brachiopod migration and palaeosea temperatures: A case study from the Jurassic of western India. Indian Journal of Geosciences 70 and 71: 269-276.

Palmer, T.J., and F.T. Fürsich. 1974. The ecology of a middle Jurassic hardground and crevice fauna. Palaeontology 17 (3): 507-524.

Palmer, T.J., and M.A. Wilson. 1990. Growth of ferruginous oncoliths in the Bajocian (middle Jurassic) of Europe. Terra Nova 2 (2): 142-147.

Palmer, T.J., and M.A. Wilson. 2004. Calcite precipitation and dissolution of biogenic aragonite in shallow Ordovician calcite seas. Lethaia 37 (4): 417-427.

Pandey, D.K., and S. Choudhary. 2007. Sequence stratigraphic framework of lower to lower middle Jurassic sediments of the Jaisalmer Basin, India. Beringeria 37: 121-131.

Pandey, D.K., S. Choudhary, T. Bahadur, N. Swami, D. Poonia, and J.G. Sha. 2012. A review of the lower-lowermost upper Jurassic facies and stratigraphy of the Jaisalmer Basin, western Rajasthan, India. Volumina Jurassica 10 (1): 61-82.

Pandey, D.K., and F.T. Fürsich. 1994. Bajocian (mid Jurassic) age of the lower Jaisalmer formation of Rajasthan, western India. Newsletters on Stratigraphy 30 (2): 75-81.

Pandey, D.K., F.T. Fürsich, and M. Alberti. 2014. Stratigraphy and Palaeoenvironments of the Jurassic rocks of the Jaisalmer Basin: Field guild Beringeria Special Issue 9: 1-111.

Pandey, D.K., F.T. Fürsich, and R. Baron-Szabo. 2009a. Jurassic corals from the Jaisalmer Basin, western Rajasthan, India. Zitteliana A48/49: 13-37.

Pandey, D.K., F.T. Fürsich, and J.G. Sha. 2009b. Interbasinal marker intervals - A case study from the Jurassic basins of Kachchh and Jaisalmer, western India. Science in China Series D: Earth Sciences 52 (12): 1924-1931.

Pandey, D.K., and D. Pooniya. 2015. Sequence stratigraphy of the Oxfordian to Tithonian sediments (Baisakhi formation) in the Jaisalmer Basin. Volumina Jurassica 13: 65-76.

Pandey, D.K., J.G. Sha, and S. Choudhary. 2006a. Depositional history of the early part of the Jurassic succession on the Rajasthan shelf, western India. Progress in Natural Science 16: 176-185.

Pandey, D.K., J.G. Sha, and S. Choudhary. 2006b. Depositional environments of Bathonian sediments from the Jaisalmer Basin, Rajasthan, western India. Progress in Natural Science 16: 163-175.

Pandey, D.K., J.G. Sha, and S. Choudhary. 2010. Sedimentary cycles in the Callovian-Oxfordian of the Jaisalmer Basin, Rajasthan, western India Volumina Jurassica 8: 131-162.

Pandey, D.K., N.K. Swami, J.K. Sharma, and M. Alberti. 2018. Callovian ammonites from a condensed horizon in the Kuldhar member of the northeastern Jaisalmer Basin (Rajasthan, India) and their biostratigraphic implications. Journal of the Palaeontological Society of India 63: 37-52.

Paul, S., T.K. Gangopadhyay, and U. Mal. 2018. A study of bioerosion of belemnites and taphonomy of cephalopods from Kuldhar member of Jurassic Jaisalmer formation from Jaisalmer, Rajasthan. Journal of the Geological Society of India 91 (6): 687-694.
Prasad, S. 2006. Ammonite biostratigraphy of middle to late Jurassic rocks of Jaisalmer Basin, Rajasthan, India. Memoirs of the Geological Survey of India 52: 1-146.

Prasad, S., R.L. Jain, and M.S. Srivastava. 2007. Record of middle Jurassic (Bathonian) ammonite genus Clydoniceras Blake from Jaisalmer Basin. western Rajasthan. Journal of the Geological Society of India 69: 53-56.

Puga-Bernabéu, Á., and C. Betzler. 2008. Cyclicity in Pleistocene upper-slope coolwater carbonates: Unravelling sedimentary dynamics in deep-water sediments, great Australian bight, ODP leg 182, site 1131A. Sedimentary Geology 205 (1-2): 40-52.

Purser, B.H. 1969. Syn-sedimentary marine lithification of middle Jurassic limestones in the Paris Basin. Sedimentology 12 (3-4): 205-230.

Rao, V.R. 1972. Subsurface stratigraphy, tectonic setting, and petroleum prospects of the Jaisalmer area, Rajasthan, India. In Mineral Resources Development Series No. 41, 366-380. United Nations: Economic Commission for Asia and Far East.

Seilacher, A. 1967. Bathymetry of trace fossils. Marine Geology 5 (5-6): 413-428.

Sharma, J.K., and D.K. Pandey. 2016. Taxonomy of late Bathonian-Oxfordian ammonites from the Jaisalmer Basin: Implications for intrabasinal litho- and biostratigraphic correlations. Journal of the Palaeontological Society of India 61 (2): 249-266.

Singh, C.S.P., A.K. Jaitly, and D.K. Pandey. 1982. First report of some BajocianBathonian (middle Jurassic) ammonoids and the age of the oldest sediments from Kachchh, W. India. Newsletters on Stratigraphy 11 (1): 37-40.

Singh, I.B. 1989. Dhosa Oolite - A transgressive condensation horizon of Oxfordian age in Kachchh, western India. Journal of the Geological Society of India 34 (2): 152-160.

Taylor, P.D., and M.A. Wilson. 2003. Palaeoecology and evolution of marine hard substrate communities. Earth-Science Reviews 62: 1-2): 1-103.

Van Wagoner, J.C., H.W. Posamentier, R.M. Mitchum, P.R. Vail, J.F. Sarg, T.S. Loutit, and J. Hardenbol. 1988. An overview of the fundamentals of sequence stratigraphy and key definitions. In Sea-Level Changes: An Integrated Approach. SEPM Special Publications, ed. C.K. Wilgus, B.S. Hastings, C.G.S.C. Kendall, H. Posamentier, C.A. Ross, and J.C. van Wagoner, vol. 42, 39-45.

Waagen, W. 1875. Jurassic Fauna of Kutch: The Cephalopoda. Memoir of the Geological Survey of India, Palaeontologia Indica, Series 9 1: 1-147.

Wilson, M.A., and T.J. Palmer. 1994. A carbonate hardground in the Carmel formation (middle Jurassic, SW Utah, USA) and its associated encrusters, borers and nestlers. Ichnos 3 (2): 79-87.

\section{Submit your manuscript to a SpringerOpen ${ }^{\circ}$ journal and benefit from:}

- Convenient online submission

- Rigorous peer review

- Open access: articles freely available online

- High visibility within the field

- Retaining the copyright to your article

Submit your next manuscript at $>$ springeropen.com 